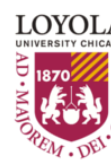

\title{
Introduction: The New Voices of Muslim Women Theologians
}

Marcia Hermansen

Loyola University Chicago, mherman@luc.edu

Follow this and additional works at: https://ecommons.luc.edu/theology_facpubs

Part of the Religious Thought, Theology and Philosophy of Religion Commons Author Manuscript

This is a pre-publication author manuscript of the final, published article.

\section{Recommended Citation}

Hermansen, Marcia. Introduction: The New Voices of Muslim Women Theologians. Muslima Theology: The Voices of Muslim Women Theologians, , : 11-34, 2013. Retrieved from Loyola eCommons, Theology: Faculty Publications and Other Works, http://dx.doi.org/10.3726/978-3-653-03238-3

This Book Chapter is brought to you for free and open access by the Faculty Publications and Other Works by Department at Loyola eCommons. It has been accepted for inclusion in Theology: Faculty Publications and Other Works by an authorized administrator of Loyola eCommons. For more information, please contact ecommons@luc.edu.

\section{(c) $($ () $\ominus$}

This work is licensed under a Creative Commons Attribution-Noncommercial-No Derivative Works 3.0 License. (c) Peter Lang, 2013. 


\title{
INTRODUCTION
}

\section{The New Voices of Muslim Women Theologians}

\author{
Marcia Hermansen
}

While it is clear that, historically and doctrinally, there is no barrier to females commenting on and interpreting Islamic sacred texts, after the first generation of Muslims, women primarily functioned as transmitters rather than as interpreters of the tradition. ${ }^{1}$ It is only with modernity and the rise of mass literacy that Muslim women, beyond the circle of a few elite scholarly families, began to have access to the education and tools needed to engage in writing interpretive theology. Of course, this could also be said to a greater or lesser extent of all major religious traditions. While much of this new Muslim theology undertaken by female interpreters is explicitly feminist or womanist, the participation of many women in Islamist or socially conservative pietistic movements has also opened up the field of religious discussion and activism to those Muslim women who seek to reaffirm many traditional Islamic tenets while also speaking in a female voice that addresses issues of special relevance to women.

The very concept of Islamic theology requires historical contextualization. Unlike Christianity, and more similarly to Judaism, law, rather than theology, became the privileged intellectual discipline in classical Islamic religious thought. The budding rationalistic theologies of ninth century Baghdad such as Mu'tazilism eventually fell into eclipse in the Sunni world. While the Sunni Asharite and Maturidite schools of thought continued to exist, their articulation was generally limited to commentary on existing texts rather than full-scale reinterpretation of revealed sources in order to make them speak to the particular concerns of a changed context. In the Shi'a world and in some areas of traditional Sufism, elements of philosophical or mystical theologizing continued. However, their main concerns were neither gender nor the challenges of contemporary social and political issues.

Terms for theology in classical Arabic are "ilm al-kaläm" and " aqìda". 'Ilm means science or discipline while kaläm literally means speech or discussion, and the scholastic "question and answer" format of early treatises on issues that impacted the Muslim community

\footnotetext{
${ }^{1}$ This is not to say that transmission is always devoid of individual input and perspectives. There were exceptions throughout history of Muslim women becoming legal experts, issuing fatwas and making legal decisions as well as, in very limited cases, speaking or writing critically about male interpreters. See, for example, Ruth Roded, Women in Islamic Biographical Collections: From Ibn Sa'd to Who's Who (Boulder, CO: Lynne Rienner, 1994).
} 
initially reflected political and subsequently more theoretical debates about issues such as "who is a Muslim" or "free will vs. determinism". A crucial debate that emerged early and continues until the present concerns the scope of applying rational or metaphorical interpretation to the revealed sources, in contrast to restricting readings of their terms and injunctions to the literal meanings, in which only texts could be used to comment on other sacred texts.

'Aqìda. the second term related to theology in the Islamic tradition, is derived from a root that conveys "binding, commitment, and contract" and suggests the binding nature of religious conviction. While Islam is not creedal in the same way as Christianity, some early Muslim figures drew up lists of basic tenets of faith.

The documents to which the terms 'aqìda or 'aq $\bar{a}$ 'id are applied vary in length, and the longer ones cannot be sharply divided from the comprehensive theological treatises (e.g. al- 'Aqīda al-Nizāmiyya by Juwaynī). The terms, however, may usefully be taken to signify compositions where the chief interest is in the formulation of doctrine or dogma, and not in intellectual discussion or argument about it. . .Creeds are often built round either the shahāda (as al-Ghazālī’s) or the tradition, which elaborates a Qur'ānic formula, that faith is faith in God, His angels, His books, His prophets, etc. (as Birgewī's). Sometimes they are included in legal treatises, as introductory statements of what it is obligatory for a Muslim to believe. ${ }^{2}$

Current lively and critical discussions about the interpretation of religion and the role of Islam in all areas of life have provoked a renewal in speculative theology among Muslims which addresses all areas of ethical, interpretive, and constructive engagement with religious teachings. When contemporary Muslim women engage in scriptural interpretation and theology they are breaking new ground in a number of areas, not only as females, but also as interpreters of the religious tradition in the context of significant contemporary challenges. Their sources cannot be limited to pre-modern theologies of 'ilm al-kalām and 'aqìda, which tended to be scholastic in argumentation and to address matters that are no longer compelling or relevant to most Muslims. Therefore, the writings of the new cohort of Muslim women theologians draw on a range of initiatives that support their project, including the following.

\section{Islamic Liberalism}

\footnotetext{
${ }^{2}$ W. Montgomery Watt, “Aḳīda,” Encyclopaedia of Islam I, $2^{\text {nd }}$ ed., eds. P. Bearman, Th. Bianquis, C.E. Bosworth, E. van Donzel, and W.P. Heinrichs (Leiden: E. J. Brill, 2011), 332.
} 
Islamic modernist or liberal thought emerged in the late nineteenth century, due to rapid social and historical change accompanied an increased acquaintance with Western postEnlightenment methodologies for reading scripture that applied historical criticism and the analysis of literary tropes and genres. ${ }^{3}$

Both secularized and explicitly religious writers and activists had an influence on reformist currents in Muslim societies. For example, Qasim Amin's Liberation of Women was thought to have been influenced by the Egyptian modernist Shaikh al-Azhar, Muhammad Abduh (d. 1905). ${ }^{4}$ Modernists such as Abduh aimed to liberate society from the effects of medieval interpretations and to ultimately transform family life and the understanding of the husband-wife relationship with its extreme gap between the sexes.

Other male Muslim liberals such as 'Ali Shari'ati (d. 1977) and Fazlur Rahman (d. 1988) presented Islam in ways that addressed the limitations placed on women by taking historical critical approaches to traditional interpretations. In particular, Rahman's approach of historically contextualizing specific verses of the Qur'an that seem to inscribe female deficiency, in order to offer a more egalitarian reading 5 influenced the present cohort of Muslim female theologians. His hermeneutic featuring a holistic approach to the message of the Qur'an is acknowledged as a formative influence by pioneering advocates of Qur'anic gender justice such as new readings undertaken by Amina Wadud and Asma Barlas. ${ }^{6}$

Charles Kurzman noted the "social location" of Muslim liberals, observing that they emerged independently and rarely read one another's work. This assertion is challenged by the case of current Muslim women theologians who often draw on international networks of activists and scholars who increasingly cooperate with one another. In fact, activists for women's advancement join with scholars by putting forward the issues that they face in local contexts, thereby encouraging feminist theologians to work on material that may address and ameliorate

\footnotetext{
${ }^{3}$ Charles Kurzman, Modernist Islam, 1840-1940: A Sourcebook (New York: Oxford, 1998) and Liberal Islam: A Sourcebook (New York: Oxford, 2002).

${ }^{4}$ Leila Ahmed, A Quiet Revolution (New Haven: Yale University Press, 2011).

${ }^{5}$ Fazlur Rahman, "'The Status of Women in Islam': A Modernist Interpretation," in Separate Worlds: Studies of Purdah in South Asia, eds. Hannah Papanek and Gail Minault, 285-310 (Columbia, SC: South Asia Books, 1982). His hermeneutic is further elaborated in Islam and Modernity: Transformation of an Intellectual Tradition (Chicago: The University of Chicago Press, 1982), 20, and Major Themes of the Qur'an (Chicago: Bibliotheca Islamica, 1980).

${ }^{6}$ Amina Wadud, Qur'an and Woman: Rereading the Sacred Text from a Woman's Perspective (New York: Oxford University Press, 1999).
} 
such concrete issues. Some of these concerns may be legal such as recognizing the need for women's rights to be framed in marriage contracts. Others are addressed by advancing new interpretations of Qur'an 4:34, the "beating" verse, while further initiatives comprise femaleempowering exegeses of sacred texts or the recovery of positive gender meanings embedded in traditional writings.

Several contributions to this collection evidence such interactions, and explicitly comment on the leading role of female Muslim scholars living in the West in laying out some of the formative approaches to Qur'anic interpretation. The most often cited works in this vein are the theological papers of Pakistani-American feminist, Riffat Hassan, a contributor to the present collection, as well as the Qur'anic studies of Amina Wadud and Asma Barlas. Notably all three have advanced degrees from the West and have held academic positions at American universities.

\section{Female Social and Political Activism and the Feminist Movement}

During the earlier decades of the twentieth century Muslim women played new and important public roles in independence struggles and nationalist movements in many parts of the Muslim world. For example, the (1892-1920) women's press ${ }^{7}$ and early female social movements that emerged in Egypt combined charitable endeavors with a desire to educate the masses and mobilize them toward independence. ${ }^{8}$ Najmabadi presents parallel developments in Iran, emphasizing the participation of women in 'nation-building' through their role in the family and the importance of education. ${ }^{9}$ This was also the period during which a Syrian woman, Nazira Zain ad-Din, wrote her re-interpretation of the Qur'anic verses that specifically concern women. ${ }^{10}$ In South Asia, Bengali writer, Rokeya Sakhaat Hussain, published her "Sultana's

\footnotetext{
${ }^{7}$ Beth Baron, The Women's Awakening in Egypt: Culture, Society, and the Press (New Haven: Yale, 1997).

${ }^{8}$ Margot Badran, Feminists, Islam, and Nation: Gender and the Making of Modern Egypt (Princeton: Princeton University Press, 1995).

${ }^{9}$ Afsaneh Najmabadi, "Crafting an Educated Housewife in Iran," in Lila Abu-Lughod, ed., Remaking Women: Feminism and Modernity in the Middle East, 91-125 (Princeton: Princeton University Press, 1998).

${ }^{10}$ Bouthaina Shaaban, "The Muted Voices of Women Interpreters," in Mahnaz Afkhami, ed., Faith and Freedom: Women's Human Rights in the Muslim Middle East, 61-77 (Syracuse: Syracuse University Press, 1995).
} 
Dream", a work of feminist science fiction, in which women take over the public sphere, in $1905 .^{11}$

We therefore find evidence for a new involvement of Muslim women as activists and scholars in various women's movements that emerged in Muslim societies early in the twentieth century, as well as in the documents that were generated within these groups. Ultimately Muslim women, like their Western feminist counterparts, sought to achieve or enhance women's rights through theoretical reconstruction, as well as undertaking practical initiatives.

In the West and, in fact, globally, the scope and theory of feminism has developed from "first wave" or early feminist concerns such as demanding female suffrage and basic rights, to a "second wave" theoretical critique of patriarchy as embedded, not only in social institutions, but also in the very ordering and construction of categories of knowledge. Women of color further criticized the overwhelmingly white and privileged nature of previous feminist agendas resulting in "cultural" or "third wave" feminism that recognized the distinctive concerns of non-Western, non-privileged females. Theoretical and theological writings by women of color hence generate their own "womanist" or, in the case of Latinas, mujerista approaches, to religion and culture. As part of this third feminist wave, the category of Islamic (as opposed to primarily secular) "Arab" or other feminisms emerged in the 1980s among Muslim women who embraced their religion and did not want to be seen as imposing and adopting Western norms. Islamic feminists seek to combine Islamic understandings with liberatory readings of classical Islamic sources, religious or historical. Some of the contributors to the present volume have suggested the coinage "Muslima" feminism to apply to this form of theologizing, inspring the title of the volume.

A continued strategy to ameliorate women's status in Muslim societies involves activism against social injustice through addressing woman-unfriendly readings of religious tradition. Like feminism in the West, Islamic feminism may be said to evolve through waves, beginning with a first impulse toward activism for basic rights such as education and the vote. Early Arab feminists such as the Egyptian, Hoda Sharawi, emerged from seclusion and demanded basic rights while participating in national liberation movements. Female social activism could be exemplified by Egyptian feminist author, Nawal al-Saadawi, who preferred to critique Arab culture rather than directly engaging Islamic religious authorities and discourse. Thus the earlier

\footnotetext{
${ }^{11}$ Rokeya Sakhaat Hussain, Sultana's Dream and Selections from The Secluded Ones (New York: Feminist Press, 1988).
} 
feminist movements in the Muslim world were primarily oriented toward secular projects and discourse.

Later, the second wave of theoretical feminism would begin to engage Islamic religious texts more directly. This may be due to the realization that religion constituted a major element in the social construction of gender roles in Muslim societies. Greater interest in religious interpretation parallels the Islamic resurgence in most of the Muslim world that marked the later decades of the twentieth century.

Fatima Mernissi, a Moroccan sociologist strongly influenced by Western critical theory, moved from predominantly social critique in her earlier works such as Beyond the Veil to considering constructions of women, power and political leadership in the deployment of religious sources. An example is her essay questioning the provenance of the hadith report, "The nation led by a woman will not prosper." 12

Her rationale for such an enterprise was that changing mass opinion on such issues would ultimately require engaging the religious sources and their interpretation directly, and that this would require mastery of methodologies of the traditional Islamic sciences, for example, evaluating the reliability of the narrators of a hadith.

\section{Leila Ahmed's work, Women and Gender in Islam: Historical Roots of a Modern}

Debate, represents an important resource for contextualizing the roles of Muslim women in the early and pre-modern periods as well as for understanding their struggle for rights in contemporary Islamic societies. At the same time, this history becomes a resource for contextualizing and contesting misogynistic interpretations and practices embedded in religious interpretation and practices.

The emergence of third wave, womanist, global, or "cultural" feminisms in the 1980s and 1990s represented an area of theorizing that challenged then-prevalent assumptions. Both secular and Islamiv feminists became more self-critical regarding the dominance of Western white middle class women's aspirations that had constituted a normative agenda assumed for all women, thereby enabling or perpetuating colonial or imperial projects. This development was especially significant for Muslim women who constituted the "Other" of traditional feminism,

\footnotetext{
${ }^{12}$ Fatima Mernissi, Beyond the Veil: Male-Female Dynamics in Modern Muslim Society (New York: John Wiley and Sons, 1975). Her chapter on the hadith is reprinted in "A Feminist Interpretation of Women's Rights in Islam," in Liberal Islam, ed. Charles Kurzman, 112-126 (New York: Oxford, 1998).
} 
and enabled diverse Muslim female voices to emerge as activists and participants who could resist such hegemony.

This also helps explain why the label "feminist" is not universally welcomed or espoused by Muslim activists or Muslima theologians due to a history that was often associated with marginalizing, ignoring, or subverting the goals of Muslim women situated in their own cultural and religious contexts.

At the same time a whole range of trends characterized as "Islamic feminism(s)"13 emerged as part of a broader spectrum of movements and thought that shared an interest in the dignity and flourishing of Muslim women. As Sa diyya Shaikh argues, "Retaining the term 'feminist' enables Muslim women to situate their praxis in a global political landscape, thereby creating greater possibilities for alliances, exchanges, and mutually enriching interaction among different groups of women."14

\section{Scriptural Feminist Methodologies in Other Religions}

Not all contemporary female Muslim theologians overtly espouse feminism, yet the work of Christian and Jewish biblical feminists ${ }^{15}$ has no doubt been influential, particularly among pioneering Muslim feminists based in the West such as Riffat Hassan, Azizah al-Hibri, and Asma Barlas. Strategies for recovering the role of women in religious traditions, as in history, value researching 'Herstory'-the recovery of important female figures, their activism, and, when available, their literary production. ${ }^{16}$ This recovered past is also a more accurate one, according to feminist Buddhist scholar Rita Gross. ${ }^{17}$ Sa diyya Shaikh further comments on how such new readings aim to redress "the androcentric silence and trivializing of women in much of the inherited historical canon." Such a project is especially important in the present because, “A

\footnotetext{
13 The primary scholarly authority on the emergence of Islamic feminisms is Margot Badran: "Feminism." In The Oxford Encyclopedia of the Modern Islamic World II, ed. John L. Esposito. (New York: Oxford University Press, 2001), 19-23, “Islamic Feminsim: What's in a Name?” in al-Ahram Weekly \#569, Jan. 17-23, 2002 http://weekly.ahram.org.eg/2002/569/cu1.htm Accessed Jan. 6, 2012, and Feminism in Islam: Secular and Religious Convergences. (Oxford: Oneworld, 2009).

${ }^{14}$ Sa diyya Shaikh, Sufi Narratives of Intimacy: Ibn Arabi, Gender, and Sexuality (Chapel Hill: University of North Carolina, 2012), 23.

15 The term "biblical" feminism is used here to refer to the approach of Christian women who pursue a woman friendly reading of the Bible and do no reject the tradition wholesale.

${ }^{16}$ A pioneering article in this area is Azizah al-Hibri, "A Study of Islamic Herstory: Or How Did We Ever Get into this Mess?” in Women's Studies International Forum 5, no. 1 (1982): 212-215.

${ }^{17}$ Rita Gross, Buddhism after Patriarchy (Albany: SUNY Press, 1993), 20.
} 
politics of recovering feminist histories thus is invaluable to those living religious communities that want to create new, bountiful, future visions for their own humanity within their traditions." $" 18$

The approach of many among the first cohort of Muslim women to reexamine the sources was both theological and-at least implicitly-feminist. Such a tendency could be termed "Qur'anic" or "scriptural" in the same way that some Christian feminsts are designated as "biblical" in orientation. Furthermore, the pioneers of Qur'anic feminism overwhelmingly followed the Muslim modernist or liberal strategy of concentrating on the Qur'an and viewing the reliability of the hadith corpus with suspicion. A number of these female Muslim theologians, in particular Amina Wadud and Asma Barlas, cite the work of Muslim liberal thinker, Fazlur Rahman (d. 1988), as an inspiration due to his initiating a hermeneutic of reading the Qur'an holistically in order to determine the spirit behind the literal force of certain injunctions. Early examples of such Muslim scriptural feminist writing include Riffat Hassan's substantial work on clearing the accretions of Biblical and non-canonical elements from the figure of Eve. According to Hassan's reading, interpretations that inscribe female deficiency and blame Eve for a Fall of humanity cannot be derived on the basis of the creation narrative as presented in the Qur'an. ${ }^{19}$

The methodologies of Muslim scriptural feminists may explicitly draw on feminist hermeneutical approaches that are willing to interrogate the dominant traditional articulations of the "true" meaning of texts. This lays the foundation for a "hermeneutic of suspicion" that can confront the hierarchical and patriarchal biases brought to bear in formulating earlier interpretations. This hermeneutic can be brought to bear on the gendered nature of language itself including the gender of particular vocabulary items and the use of pronouns, and can apply to more explicit and direct embedding of gender disparities within canonical formulations.

Continuing the strategy of re-reading and re-translating existing legal and theological interpretations and resources from a woman's perspective, Amina Wadud's groundbreaking study of the Qur' $\mathrm{n}^{20}$ explores not only gendered language but also the various female characters

\footnotetext{
${ }^{18}$ Sa'diyya Shaikh, Sufi Narratives of Intimacy, 25, 26.

${ }^{19}$ Riffat Hassan, "The Issue of Woman-Man Equality in the Islamic Tradition," in Women's and Men's Liberation: Testimonies of Spirit, eds. Leonard Grob, Riffat Hassan, and Haim Gordo, 65-82 (New York: Greenwood Press, 1991).

${ }^{20}$ Amina Wadud, Qur'an and Woman: Rereading the Sacred Text from a Woman's Perspective (New York: Oxford University Press, 1999).
} 
in the sacred text. These include the figures of Sarah and Mary as depicted in the Qur'an, and even the role of the female houris in the Qur'anic portrayal of the afterlife.

Increasingly, Muslim women theologians engage both the hadith and the later tradition, including both Islamic legal theory and rulings, ${ }^{21}$ and the philosophical and Sufi heritage, in some cases reading against the grain and questioning embedded patriarchal assumptions. Exemplary in this regard would be the work of Sa diyya Shaikh on hadith depicting women in Islamic eschatological imagination, ${ }^{22}$ and her recent studies of reading Sufi thought, in particular the work of Ibn Arabi, as opening up new understandings of gender dynamics within Islamic thought. ${ }^{23}$ Indonesian-American feminist theologian, Etin Anwar, who has also authored a chapter in the current collection, has contributed a monograph, Gender and Self in Islam, ${ }^{24}$ in which she draws on both Islamic scriptures and the philosophical tradition to explore the construction of gender in Muslim sources as based on the hierarchical principles structuring understandings of human reproduction, especially the role of women in conception. Through confronting such embedded inequality, Anwar attempts to redress the alienation of the self as part of recovering the Muslim woman's sense of individuality, agency, and autonomy.

Muslim feminist legal scholar, Kecia Ali, noted that many of the initial efforts by Muslim scriptural feminists concentrated on Qur'anic texts and did not explicitly engage the intricacies of the legal tradition (fiqh). ${ }^{25}$ This present collection features several articles by Muslim women theologians that directly engage the legal tradition, demonstrating the growth of work in this area and the broadening of scriptural methods beyond the initial "Qur'an only" focus.

\section{Pietistic Movements: Islamist or Islamic Feminisms?}

With the rise of grassroots Islamist movements and the moderation and feminization of membership, the role of such women in gender activism needs to be taken into account.

\footnotetext{
${ }^{21}$ Kecia Ali's book, Sexual Ethics in Islam: Feminist Reflections on Qur'an, Hadith and Jurisprudence (Oxford: Oneworld, 2006), explicitly positions itself as engaging the resources of fiqh and juristic deliberations rather than adopting a "Qur'an only" feminist stance, $x x$.

${ }^{22}$ For example, Sa diyya Shaikh's study of the depiction of women in hadiths on the Last Days, "Knowledge, Women and Gender in the Hadith: A Feminist Interpretation," Islam and Christian-Muslim Relations 15 (1, 2004$)$ : 99-108.

${ }^{23}$ Including the paper reprinted in the current collection and her Sufi Narratives of Intimacy: Ibn Arabi, Gender, and Sexuality (Chapel Hill: University of North Carolina Press, 2012).

${ }^{24}$ Etin Anwar, Gender and Self in Islam (London: Routledge, 2006).

${ }^{25}$ Ali, Sexual Ethics and Islam, xx.
} 
Increasingly, Islamist women or simply "pious" Muslim identified females are significant actors and in some cases writers and theorists of gender issues. Notable in this regard are figures such as Zaynab al-Ghazzali (d. 2005) and Bint as-Shati (d. 1998) in earlier cohorts. Zaynab alGhazali's Association of Muslim Women (1920s) that emerged parallel to the Muslim Brotherhood, but also the women's movement promoting liberal ideas, emphasized the religious dimension in women's education. In some ways, al-Ghazali helped to provide the impetus for men and women Muslim activists who emerged in the 1980s. Souch individuals sought to return liberated, educated women, especially university students, from miniskirts and mores imported from the 'West' to a an embrace of personal piety and search for Islamic authenticity. Manifestations of this trend included adopting globalized Islamic dress (hijab) and seeking "traditional" Islamic knowledge. ${ }^{26}$

Currently we may cite Egyptian political scientist, Heba Raouf Ezzat, as one representative of Islamic intellectual feminism. ${ }^{27}$ In Pakistan and now Canada, the al-Huda movement inspired by Niqab-wearing Islamic scholar, Farhat Hashmi, ${ }^{28}$ runs courses enabling Muslim women to acquire fundamental knowledge of Qur'anic and hadith studies. Established in 1994, the al-Huda course is franchised across Pakistan and operated locally by females who have been her students. Scholarly views and public opinion debate whether Hashmi is an empowering innovator for female Muslims or a regressive force. In 2004 Hashmi relocated to Toronto, Canada, where since 2005 she has operated the al-Huda Institute to train diaspora South Asian women in her educational method and interpretations.

Saba Mahmood conducted seminal research on the pious women of Egyptian women's mosque movement who reclaimed public religious spaces as part of pursuing Islamic knowledge and embracing a personally religious lifestyle. ${ }^{29}$ Mahmood made the critical argument that such women, by mastering the discourse of classical Islamic texts and argumentation and adopting a habitus of modest and compliant behavior, express their agency and autonomy-both "feminist" objectives, within an Islamic framework. An additional example of a grassroots movement based

\footnotetext{
${ }^{26}$ Leila Ahmed's, A Quiet Revolution (New Haven: Yale University Press, 2011) explores this global return to Islam on the part of Muslim women with specific interest in "reveiling."

${ }^{27}$ Some of Raouf's writings in English may be found at http://www.heba-ezzat.com/category/english/ (accessed November 26, 2011). A parallel Arabic site is also available.

${ }^{28}$ Studied by Sadaf Ahmed in Transforming Faith: The Story of al-Huda and Islamic Revivalism among Urban Pakistani Women (Syracuse, NY: Syracuse University Press, 2009).

${ }^{29}$ Saba Mahmood. "Feminist Theory, Agency, and the Liberatory Subject: Some Reflections on the Islamic Revival in Egypt," Temenos 42, no. 1 (2006): 31-71.
} 
on Muslim females as "pious subjects" would be the Qubaysiyyat in Syria, which is an initiative exclusive to women that is highly conservative in maintaining Islamic norms, while providing an independent space for female leadership and interpretation within classical strictures. ${ }^{30}$ Likewise women in traditional Sufi orders, ${ }^{31}$ or in post-tariqa ${ }^{32}$ pious movements such as the Turkish Nur and Gulen communities ${ }^{33}$ have been studied for their access to leadership and their participation, which they exercise despite being part of socially conservative and male dominated groups.

\section{Muslim Women as Theologians}

Most, but not all, current theological interventions on the part of Muslim women are informed by an awareness of gender studies and the broader context of studies of women in religion. Conservative discourses about women in religion, or women in Islam specifically, often present an essential concept of the "muslimwoman", ${ }^{34}$ who may be the abstract and idealized "woman" of religious ideology and pious fantasy. This stands in contrast to speaking about "women", the experiences and agency of actual Muslim females in particular contexts.

Noted scholar of women and religion, Susan Sered, suggests that there are four positions that members of the general public, and to a degree, scholars, are taking today in their discourses and understandings of women and religion. The first position could be termed "patriarchal and proud of it. ${ }^{~}{ }^{35}$ Here there are no apologies for gender discrimination; patriarchy is the way it is, part of the divine order, and that is good. Secondly, there is the position that the founders of religions or the prophets such as Jesus or Muhammad were the first feminists. They initially brought gender egalitarian messages but then something went wrong over time and this was lost,

\footnotetext{
${ }^{30}$ Aurelia Ardito, "Les cercles féminins de la Qubaysiyya à Damas," in Les engagements féminins au Moyen-Orient (XXe-XXIe siècles). Le mouvement social (Paris: La Découverte, April-June 2010), 77-88.

${ }^{31}$ For an overview of scholarship in this area see Marcia Hermansen, "Women in Sufism: Turkey, South Asia, Central Asia, Afghanistan, Iran, Caucasus and the Middle East," in Encyclopedia of Women in Islamic Cultures, $3^{\text {rd }}$ ed., ed. Suad Joseph, 766-770 (Leiden: Brill, 2005).

32 Tariqa is the term for Sufi "order" in the sense of a movement of formally initiated adherents who practice specific spiritual regimens. Post-tariqa movements loosen or eliminate such bonds and rituals.

${ }^{33}$ Margaret Rausch, "Gender and Leadership in the Gülen Movement: Women Affiliates' Contributions to East-West Encounters," forthcoming in East-West Encounters: The Gülen Movement, eds. N. Gallagher and K. Moore,(Baton, FL: Brown Walker Press, 2012).

${ }^{34}$ Miriam Cooke, "The 'Muslimwoman,"” Contemporary Islam 1 (2007): 139-154. This article develops a critical theory of how post 9/11, the role of being a "Muslim woman" is deployed surrounding topics such as veiling, commodification, and political dimensions to erase the individual identity of Muslim female agents.

${ }^{35}$ I owe the broad outlines of this model to a lecture on women and religion given by Susan Sered at Loyola University Chicago in 2006.
} 
so our task today is to recover the original message of gender justice. The third position is that religion, in general, is not fair to women and therefore activism to make theological and institutional change is required. The fourth position entails a radical rejection of religious tradition that is irreparably patriarchal and oppressive for women. In this case women would have to step outside of the existing religions completely and start all over. Representatives of all of four positions can be found to varying extents in all religions today.

Therefore we observe female Muslim theology in the writings of activists, literary figures, or academics. In fact, the shifting institutional context of women's learning and professing authority has had a dramatic effect on the expansion and global networking of activists and scholars whose works address such issues from within the tradition. The authority of holding an academic degree and position within a university system has increasingly allowed Muslim women to present ideas that challenge traditional perspectives. For example, several of the Turkish contributors to the present volume were trained in a system that featured traditional Islamic education on the imamhatip model $^{36}$ at the initial stages, followed by university level courses in Islamic methodology that included historical critical methodologies. The very existence of this volume owes itself to new theological initiatives in Europe, specifically Germany and Austria, that support the creation of academic positions on par with those accorded to Christian faculties within the academic system. Even in Muslim majority societies, the emergence of female teachers and preachers, whether with the support of governments or as a social trend, ${ }^{37}$ has opened up new spaces for issues of women's rights, religious practice, and dignity to be discussed and challenged. ${ }^{38}$

The disciplinary location of many other Muslim women writing on religious topics is less easily defined as "theological" since a secular academic formation in religious studies, area studies, or the social sciences implies a constructivist and critical attitude to sources which may either bracket the "faith" question or assume that it is socially or historically constructed. Liberal

\footnotetext{
${ }^{36}$ These were secondary schools geared to training imams that replaced the madrasa system in the Turkish republic. Graduates now often go on to university degrees in theology.

${ }^{37}$ Margaret Rausch, "Women Mosque Preachers and Spiritual Guides: Publicizing and Negotiating Women's Religious Authority in Morocco," in Women, Leadership and Mosques, eds. H. Kalmbach and M. Bano, 59-84 (Leiden: E. J. Brill, 2001); Mona Hassan, "Reshaping Religious Authority in Contemporary Turkey: StateSponsored Female Preachers," in Women, Leadership and Mosques, eds. H. Kalmbach and M. Bano, 85-104 (Leiden: E. J. Brill, 2011).

${ }^{38}$ Some of this leadership in the Arab world is depicted in the 2009 documentary film, Veiled Voices, directed by Brigid Maher.
} 
and progressive Muslims may not see their work as "theological" in a uniquely privileged or normative sense, and yet may find it engaging and informing issues that are critical to a theological project of gender justice within contemporary Islamic thought.

In summary, the scope and definition of Muslim women writing theology is far from clear and determined. Many respondents to our call for papers offered material that focused on Muslim women in particular national or regional contexts or that addressed issues of cultural oppression and social injustice, without engaging ideas or formulations that could be considered "theological." Other proposals, remarkably, offered a rehash of basic rule-based manuals for female comportment according to classical norms of Islamic law. What this tells us is that the field of "Muslima" theology is still developing in conversation with global activism for Muslim women's rights, new academic and institutional contexts for higher level studies of the Islamic tradition, and to an extent, more traditional institutions and discourses of Islamic learning. It is our hope that this collection of papers will encourage and inspire further work in this developing area, and provide a resource for scholars, activists, and individuals concerned with the question of Muslim women's flourishing and expression in a whole range of contexts. 


\section{The Papers}

In this pioneering collection of original articles we have tried to be representative and diverse; still we find a predominance of articles authored by Muslim women living in the West. This is perhaps due to the fact that the academic and institutional contexts in America and Europe are still, up to this point, the most developed in supported women's studies in religion. This tendency has been observed by several of the contributors to the volume within their chapters. In the rest of the world the most fertile areas where we see the development of female activism, if not theologizing, are South Africa and Malaysia, both Muslim minority contexts. South Asian and Turkish scholars had previously tended to write in a secular activist vein. More recently, the growth of Muslim women's participation in Islamic higher education in Turkey, in particular in theology departments, has opened up possibilities for female theologians trained in Arabic and the traditional sources, yet having a commitment to a more equitable social and legal system. ${ }^{39}$ This volume welcomes two writers from Turkey, and in fact two of our editors are also of Turkish background, while now based in the German-speaking academic milieu. This also raises our awareness to the fact that Europe, with its growing Muslim population, is likely to become a fertile ground for a new wave of Muslim women theologians, especially since governments and local institutions are realizing the importance of supporting Islamic education and incorporating Muslim participants in the training of teachers and scholars of religious studies and theology.

The volume is divided into four thematic sections.

\section{Part One: $\underline{\text { Muslim Women as Theologians: Historical and Contemporary Perspectives }}$}

\footnotetext{
${ }^{39}$ On the factors behind the rise in Turkish women studying theology and becoming government appointees as academics or preachers see Mona Hassan, "Women Preaching for the Secular State: Official Female Preachers (Bayan Vaizler) in Contemporary Turkey," International Journal of Middle East Studies 43 (4, 2011): 451-473; "Women at the Intersection of Turkish Politics, Religion, and Education: The Unexpected Path to Becoming a StateSponsored Female Preacher," Comparative Islamic Studies 5 (1, 2009): 111-130. These factors include the headscarf ban in Turkey which led women to study theology because there was more tolerance in these faculties and the system of determining university entrance which made it difficult for graduates of religious high schools to enter other fields.
} 
In the first section four writers address the development of women's theology and activism within Islam, covering both classical and contemporary periods.

Volume co-editor Ednan Aslan in his essay, "Early Community Politics and the Marginalization of Women in Islamic Intellectual History", supports Muslim women theologians who are attempting to contest and resist centuries of marginalization by misogynistic interpretations of the tradition. Aslan takes a liberal stance in critiquing early political developments in the Muslim community that marked certain interpretations as universally applicable while these could be read as historically conditioned. While similar arguments about what went wrong in the construction of gender in Islamic theology and law have been advanced by many previous scholars, Muslim and non-Muslim, Aslan offers a more explicit textual background for his evidence based on original Arabic sources. He is unabashed in criticizing excessive devotionalism to an idealized past for allowing untenable pronouncements about the Muslim female to remain unchallenged in many quarters until the present.

Zainab al-Alwani alerts us to the significant role played by the women in the time of the Prophet Muhammad, in particular the role of ' $\bar{A}$ 'isha as an early activist for women's rights and interpreter of revealed sources. She assesses this role and the general impact that women had on religious scholarship at the advent of Islam. In particular, women's role in the preservation and transference of knowledge has been crucial in Islamic history, and the article traces the genealogy of women's involvement in this essential endeavor. In an effort to reclaim this tradition, the article looks at reports concerning 'A' 'isha's role, highlighting her methodological contributions to the interpretive tradition, and the active debates she engaged in with the companions of the Prophet in matters of ijtihad. The article then calls attention to several of the causes and effects of the waning of women's status within the realm of religious scholarship and points to the binding nature of religious tradition for the majority of the Muslim world. It argues that women's concerted participation in religious scholarship is essential for enhancing legal justice, promoting women's engagement in socioeconomic and political development, and advancing social justice. The article suggests that in order for their participation to be perceived as legitimate, Muslim women scholars need to retrieve the prophetic legacy in the context of changed conditions in modern times. Recognition of women engaged in religious scholarship, the paper concludes, will help the efforts of female empowerment and work against the notions of passive Muslim women who must accept patriarchal interpretations of religious texts. 
Ndeye Adújar and Aysha Hidayullah consider trends in contemporary feminist work on the part of Muslim women scholars. Andujar, an activist for Muslim women's rights located in Spain, gives us particular insights into developments in the European sphere while Hidayatullah analyzes academic work produced in North America or at least heavily influenced by currents in American Muslim women's theologizing.

Ndeye Adújar, Vice President of Junta Islamic Catalan, Spain, in her article, “Feminist Readings of the Qur’ān: Social, Political, and Religious Implications”, considers the opportunities that a feminist reading of the Qur'an opens up for a rethinking of social and political mores in our contemporary world. It discusses the multiple meanings attached to key concepts in Islam, including the word Islam itself, and thus moves on to explore the perceptions of 'Islamic feminism' discussing the meanings suggested by Ziba Mir Husseini and Margot Badran. Juxtaposing a 'masculine' understanding of prophethood and a feminist hermeneutics, it argues for the perception of the Muslim umma as an interpretative community. The feminist readings the article points to include critical analysis of the hadith, the centrality of the Qur'an, the principle of tawhid, and treating the Qur'an as a text that redresses patriarchal inequalities. Each country reacts differently to the emergence of a feminist theology according to its own social and political environment. Adújar argues that in each particular case, a feminist reading of sacred texts can bring about an awareness of difference that can benefit the unprivileged in the society. After a transnational overview of such feminist interpretations, Adújar discusses movements such as the Egyptian daiyat, the Syrian Qubaysiyyat, and the Moroccan murshidat as local examples of women's spiritual leadership and agency.

Aysha Hidayatullah's chapter is an overview and analysis of the contributions of twentieth and twenty-first century Muslim women scholars located in (or directly engaged in conversations in) the United States who are engaged in feminist interpretations of the Qur'ān. It argues that their works constitute the cohesive field of Muslim feminist theology in the United States. The works of the following scholars are studied in depth: Riffat Hassan, Azizah al-Hibri, Fatima Mernissi, Amina Wadud, Asma Barlas, Sa'diyya Shaikh, and Kecia Ali. The article identifies and closely examines three major sets of interpretive strategies that collectively emerge from their works: 1) historical contextualization; 2) holistic reading; and 3) the tawhidic paradigm. The historical contextualization method consists of: researching the occasion of a verse's revelation; distinguishing between descriptive and prescriptive verses of the Quran; 
distinguishing between universal and particular verses; and locating the role of historical biases about gender and biological essentialism in the interpretive arguments of traditional exegetes of the Qur'an. This holistic method treats the Qur'an as a unified document whose meanings are understood by analyzing the whole of the text. This method consists of tracing how linguistic terms evolve throughout the Qur'an, reading the Qur'an intra-textually (i.e., comparing verses to one another instead of reading them in isolation), and reading Qur'ānic verses in light of the Qur'ann's overall movement toward advocating justice for all human beings. Finally, the methodology of a tawhidic paradigm involves arguing for the ongoing interpretation of Qur'ānic verses, based on God's supreme authority in relation to human beings' temporal and flawed understanding, as well as distinguishing between the text of the Qur'an and its human interpretation.

\section{Part 2: Religious Anthropology and Muslim Women}

One of the most fundamental and central concerns for today's Muslim woman theologian is the area of religious or theological anthropology.

We are delighted to have a new contribution by the pioneering Pakistani-American scholarly activist and theologian, Riffat Hassan, who addresses the concept of whether there is a "fall" in Islamic theology and the specific association of the female with such a concept.

In her contribution, Riffat Hassan, whose seminal work has proven influential among many other contributors to this collection, focuses on the story of the 'Fall' - the exodus of Adam and Eve from Paradise - as it is recounted in both Genesis 3 and the Qur'an.

The Genesis story has commonly been understood as assigning the primary responsibility for man's 'Fall' to the woman who is consequently to be regarded with hatred, suspicion and contempt. The Qur'anic texts on the subject of the human pair's transition from heaven to earth, however, do not support the idea of the 'Fall' and hold man and woman equally responsible for an act of disobedience which they acknowledge and for which they are forgiven by God.

Hassan's chapter is therefore an endeavor in comparative theological anthropology that examines the relevant Biblical and quanic texts and points out the differences in their context, background and content. It concludes that although, in general, Muslims, like Jews and Christians, believe that the woman was the agent of man's 'Fall', this belief is not grounded in an 
accurate reading of the Qur'an. The methodology therefore is solidly located in Hassan's strategy of Qur'anic feminism that recovers the more neutral or even gender equitable resources of the Qur'an on its own, unclouded by the patriarchal traditions that color hadith reports and later male legal interpretations.

Two writers in this section are Turkish female theologians. Arpagus and Tuksal have been extensively trained in the classical sources of law, hadith, and 'ilm al-kaläm (theology) and bring to their papers a new depth of engagement with the classical sources. They are rising lights among Turkish feminist interpreters of Islam and these articles reflect some of their significant and original work in this area.

In her contribution, Hatice Arpagus, who is currently a researcher in the Faculty of Divinity, Marmara University, Istanbul, provides a detailed analysis of the female's role in the Creation story, an essential foundation for how Muslim women are framed within Qur'anic theological anthropology.

Staring with Qur'an 4:1, the study continues to consider the general tone/spirit of the Qur'an especially the verses concerning women's role in creation. The method involves scrutinizing the vocabulary associated with creation featured in these verses, as well as the interpretations offered in major commentaries (tafsīrs). Since the literal wording (nașș) does not provide details of any actual physical process, the spiritual and religious implications of the wording of these Qur'anic creation narratives are explored.

In her contribution to the volume, Hidayet Şefkatli Tuksal, member of the Capital Women's Platform, Ankara, notes that for the last twenty years--Muslim women have been struggling with the prejudices directed at them from the West while at the same time trying to come to terms with negative and misogynistic interpretations derived from their own religious sources. The most important of these resources, the Qur'ān and the hadith, are being read anew by Muslim women theologians trying to come to new interpretive conclusions relevant to today's world. Her essay presents results of her doctoral research on the hadith published in Turkish, The Projections of Misogynist Discourse in the Islamic Tradition. ${ }^{40}$ As a Muslim woman theologian, Tuksal critiques research that papers over the controversial questions of interpretation and exposes certain tensions that she has experienced as a 'female' researcher grappling with her Muslim identity.

\footnotetext{
${ }^{40}$ Hidayet Şefkatlı Tuksal, Kadın karşıtı söylemin İslam geleneğindeki izdüşümleri (Ankara: Kitabiyat, 2001).
} 
Finally in this section we hear from Muna Tatari, a contributor based in a theological faculty in Paderborn, Germany. With the initiatives undertaken by the German and Austrian governments to support the indigenization of Islamic theology as a field in local academic institutions, we may expect increased productivity in this area. Tatari's paper on the interpretation of the Qur'ān and its liberatory possibilities notably draws on material from female theologians and other academic advocates of Islamic gender justice. Her perspective therefore draws, as does Hidayatullah's, on the new writings of feminist Muslim theologians in Western contexts.

Tatari argues that within the Islamic tradition, women have experienced marginalizing textual interpretations and practices for centuries. Traditional theological concepts of male and female have lead to patriarchal interpretations of religion in the past that still persist. This chapter explores the ways in which Muslim female scholars are challenging these interpretations today. Premised on the idea of a righteous God who desires fair and egalitarian conditions for men and women, women now seek to expand a gender-equitable hermeneutics for Islam's foundational texts. This endeavor offers a fresh look at the methodology of Islamic strategies for deriving meaning and law making such as qiyas (analogizing), 'aql (use of reason) and $i j m \bar{a}^{\prime}$ (consensus). This chapter is directed toward formulating a potentially empowering new hermeneutic for theologizing on the part of Muslim women and their supporters.

\section{Part 3: Muslim Women and Islamic Religious Law}

Two of our authors in this section, Celene Ayat Lizzio and Carolyn Baugh, are completing graduate degrees in the academic study of Islamic thought at major research universities in the United States. They represent a new trend in the West of engaged Muslim women from Western backgrounds tackling the classical sources in Arabic and providing detailed and tightly argued new interpretations in Islamic law that both take the tradition seriously and engage with its most important classical interlocutors.

Lizzio's chapter on "Reading of the Laws of Purity and Ritual Preclusion" analyzes contemporary female hygiene manuals and fatwas issued by Sunni and Shi'a authors that treat the subject of female reproductive-related im/purity. These manuals and fatwas are informed by and in turn, entrench, gender difference perceived through somatic indicators. Women's pietistic 
capacity is regarded as 'weak' and deficient through these indicators. The article problematizes male epistemological authority over female bodies and argues that normative purity rules are phallocentric. Such a view facilitates the construction of female subjects who remain only partial participants in the most sacred of pietistic rites. The article calls attention to notions of spiritual purity in the Qur'ān and aims to give precedence to these notions over concerns of bodily cleanliness. Lizzio proposes alternative theological possibilities in order to enliven critical discussion of the interests of Muslim females as they navigate their religious values, genders, and sexualities vis-à-vis religious law.

Carolyn Baugh offers a new and startling look at "Ibn Taymīya's Feminism?” in the light of controversial fatwas that Ibn Taymiya issued on divorce that he maintained even in the face of imprisonment. Ibn Taymīya (d. 1328) was imprisoned in the Citadel at Damascus for his stance against the validity of the single utterance of a triple repudiation (tala $q$ ). His controversial position flew in the face of prevailing Hanbali thought on the matter and also of an established juristic consensus. By tracing the contours of Ibn Taymìyya's thought on the Triple Talāq form of dissolution of marriage, looking in particular at his Fatāwa , which he was banned from giving by the Sultan, the chapter attempts to understand why his positions were deemed to be so dangerous to the state. Further, the article will explore Ibn Taymìyya's thoughts on intentionality in law, questioning his motivations for such self-sacrificing action on what could be perceived as a topic related mainly to women's rights. Ultimately, the paper reveals insights into how jurists dealt with repudiation as a form of dissolution of marriage and exposes fourteenth century debates regarding Triple Talāq, a topic that remains relevant for Muslim family law today. By exploring a Muslim thinker outside the "canon" of female friendly sources, Baugh undertakes an adventurous sort of recovery of a "usable past" for Muslim women.

In our third chapter in this section, Indonesian-American feminist theologian, Etin Anwar, looks at the debates in the Indonesian context that arose in the wake of Amina Wadud's public gesture of leading a mixed gender congregational prayer in New York City in 2005. The chapter addresses questions of gender in Islamic ritual practice while bringing to light specifically Indonesian debates around woman-led congregational prayer. Anwar's chapter provides original insights into the global reverberations of Amina Wadud's controversial initiative by analyzing diverse reactions on the part of Indonesian female scholars and activists 
for women's rights. Female scholars in Indonesia recognize that although the state must take a role in regulating equality, without a grassroots movement nothing can be accomplished.

The final chapter in this section is the only one in the present volume from the Shi'a context, authored by Rabha Al-Zeera who is a research scholar at the Tawheed Research Institute in Bahrain. The "beating” verse, Qur'ān 4:34, has been explored by a number of Muslim feminist scholars and theologians searching for a way to recover a palatable, if not woman-friendly, reading of what is perhaps the most intransigent pronouncement of the sacred scripture for feminist interpretation. ${ }^{41}$

Al-Zeera's reading is relatively conservative in that she argues that the scope of this injunction to "beat" an erring wife should be applied only in the extreme case of the wife's infidelity. For al-Zeera the problem is socio-historical, in that the verse has enabled males to practice violence against women. Taking a 'traditional' approach to the verse (4:34), al-Zeera, drawing on the resources of traditional Qur'ānic and legal commentaries, argues that this verse does not encourage violence against women.

Taking a holistic approach, this article clarifies the context of the verse to emphasize that the conditions for the 'beating' are very specific, and can be implemented only in cases of infidelity of the wife. The article aims to refute the commonly held belief that God has ordered men to beat women because men are superior to women. She aims to disprove the claim for male superiority that has unfortunately been used to inculcate further perceptions detrimental to women such as their not having agency or the capacity to hold public office.

\section{Part 4: Muslima Constructive Theology}

The final section of this volume exposes the latest trends in new areas of Muslim women's theological writings — religious pluralism, Muslima womanism, and renewed ontological reflections, in this case inspired by Sufi thought.

\footnotetext{
41 Al-Zeera was informed of such scholarship by the editors but was not interested in engaging it. Examples of Muslima theological work on 4:34 that takes such a perspective are the special issue of Comparative Islamic Studies $2(2,2006)$ that includes several papers on this verse including Ayesha Siddiqua Chaudhry, "The Problems of Conscience and Hermeneutics: A Few Contemporary Approaches", 157-170; Kecia Ali, "The best of you will not strike:" Al-Shafi'i on Qur'an, Sunnah, and Wife-Beating”, 143-155; Laury Silvers, 'In the Book We Have Left Out Nothing': The Ethical Problem of the Existence of Verse 4:34 in the Qur'an”,171-180. See also F.V. Greifenhagen, "North American Islamic feminist interpretation: The case of sūrah 4:34, with a comparison to Christian feminist interpretation", Studies in Religion/Sciences Religieuses 33 (1, 2004): 51-70.
} 
In her chapter on an approach to religious pluralism, Jerusha Tanner Lamptey uses the term "Muslima" theology in coinage that evokes "womanist" and "mujerista" sub-genres of feminist theorizing and theologizing that emerge as part of the third wave of culturally sensitive feminist theory. Her chapter is a constructive theological effort toward formulating an Islamic theology of religious pluralism that draws insights from three distinct approaches: contemporary Muslim women's interpretation of the Qur'ān, feminist theological approaches to religious pluralism, and Toshihiko Izutsu's semantic analysis of the Qur'ān. In brief, it seeks to extend reflections on the concept of sexual difference to the understanding of religious difference.

Lamptey's chapter extends Muslim women interpreters' hermeneutical method and conception of human difference from the topic of sexual difference to the topic of religious difference. Integrating the concepts of universal humanity, divinely intended and teleological diversity, and lateral and hierarchical difference, it proposes a new theological approach to understanding religious diversity. Beginning with a brief sketch of two dominant trends and the shortcomings of the shared conception of religious difference in contemporary Islamic discourse on religious pluralism, it explores the manner in which Muslim women interpreters of the Qur'ān depict human difference. It then indicates ways in which their specific conceptions of difference can guide the articulation of an alternative conception of religious difference, thus forming the basis of the novel approach of Muslima theology of religious pluralism.

Debra Majeed's chapter reflects her pioneering work in the field of "womanist" Muslima theology, bringing her into conversation with feminist theologians of color across religious traditions. $^{42}$

African American Muslim women serve as a point of resistance to monolithic views of black women and religion, but their experiences have garnered scant scholarly attention. Too often, the particularities of African American approaches to Islam are overshadowed by the universality routinely accorded to black Christianity, leaving unaddressed important religious and cultural issues related to black spirituality in the United States. This chapter offers a way to fill that void with a framework that strives to return to African American Muslim women the power to name their own reality. It explores Muslim womanist philosophy as an approach that represents the sociopolitical conditions of African American women whose material reality is

\footnotetext{
${ }^{42}$ Debra Mubashshir Majeed. "Womanism Encounters Islam: A Muslim Scholar Considers the Efficacy of a Method Rooted in the Academy and the Church." In Deeper Shades of Purple: Womanism in Religion and Society, ed. Stacey M. Floyd-Thomas, 38-53. (New York: New York University Press, 2006).
} 
confounded by tri-dimensional oppression. Majeed also considers the sites of struggle of African American Muslim women and their conscious integration of religion in their daily lives as a lens into the three worlds they traverse: the mosque, the black community, and American society. Building upon the religious and intellectual journey of the author, the essay challenges the authenticity of conventional portrayals of African American Muslim women, their communities, and their realities.

The final chapter by South African Muslim feminist scholar, Sa ${ }^{\circ}$ diyya Shaikh, is constructivist in the sense of exploring the resources of Sufi thought and practice for creatively rethinking the ontological assumptions about gender embedded in Islamic law and legal reasoning. Sufi readings of gender, in particular those of Ibn Arabi, suggest an approach to gender sustained by "a holistic view of community" rather than a simple notion of gender equality. The ultimate goal of human spiritual refinement entails gender equality as part of a larger spiritual and ontological vision. 